\title{
Changes in Land Use and Land Cover of Düzce Province (1990-2018)
}

\section{Düzce İli Arazi Kullanımı ve Arazi Örtüsünde Meydana Gelen Değişimler (1990-2018)}

\author{
Ahmet Emrah SIYYAVUŞ ${ }^{1}$ ( \\ ${ }^{1}$ Arş. Gör. Dr., Marmara Üniversitesi, Fen-Edebiyat Fakültesi, Coğrafya Bölümü, İstanbul, Türkiye
}

ORCID: A.E.S. 0000-0003-1116-1275

\begin{abstract}
In the present study, the land use and land cover (LU/LC) of Düzce province, belonging to the years 1990, 2000, and 2018, were examined in the Western Section of the Black Sea Region. According to the data that we have used from the CORINE database, 7 LU/LC classes were defined; artificial, agricultural, transitional vegetation, pasture, wetland, woodlands and other areas. In this context, the changes have been occurred in the area ( $\left.\mathrm{km}^{2}\right)$ in LU/LC during the 28 years from 1990 to 2018 and discussed the reasons for these changes. Also, in the study, it was revealed on which lands the changes in LU/LC were concentrated using ArcGIS 10.4 and TerrSet programs. Attempts have been made to contribute to the sustainable and efficient use of the land by associating the changes in the LU/LC of Düzce province with soil-cover, land-use capability, climate, and population characteristics. It has been noticed that a significant part of the artificial areas, which are in continuous development, has expanded towards the agricultural lands. Also, it was determined that the area that LC/ $\mathrm{LU}$ expanded the most was agriculture, and the places where LC/LU decerased its area the most were forest areas. Therefore, we have revealed that the major reason for the negative change in the forest lands is the expansion of agricultural areas.
\end{abstract}

Keywords: Land Use, Land Cover, Düzce Province

\section{Öz}

Bu çalışmada Batı Karadeniz bölümünde yer alan Düzce ilinin 1990, 2000 ve 2018 yıllarındaki arazi kullanımı ve arazi örtüsü (AK/AÖ) incelenmiştir. CORINE veri tabanına ait verilerin kullanıldığı çalışmada yapay alanlar, tarım, orman, bitki geçiş alanları, mera, sulak ve diğer alanlar olmak üzere 7 AK/AÖ sınıfı belirlenmiştir. Bu bağlamda çalışma kapsamında 1990 yılından 2018 yılına kadar geçen 28 yıllık süreçte AK/AÖ'de alansal olarak (km²) meydana gelen değişimler ve bu değişimlerin nedenleri üzerinde durulmuştur. Ayrıca ArcGIS 10.4 ve TerrSet programlarının kullanıldığı çalışmada AK/AÖ'deki değişimlerin hangi araziler üzerinde yoğunlaştığı ortaya konulmuştur. Bunlara ek olarak çalışma sahasına ait arazi kullanım kabiliyeti haritası ile arazi örtüsü haritası çakıştıılarak tarıma elverişli alanların ne şekilde kullanıldığını ve bu eğilimin ne yönde olduğu analiz edilmiştir. Düzce ili AK/AÖ'de meydana gelen değişimler; toprak örtüsü, arazi kullanım kabiliyeti, iklim ve nüfus özellikleriyle ilişkilendirilerek arazinin sürdürebilir ve verimli şekilde kullanılmasına katkıda bulunulmaya çalışılmıştır. Nitekim sürekli gelişim içerisinde olan yapay alanların önemli bir kısmının tarım arazileri üzerinde genişlediği görülmüştür. Ayrıca kapladığı alanı en fazla genişleten AK/AÖ'nün tarım, en fazla daralmanın ise orman alanlarında olduğu tespit edilmiştir. Orman arazilerindeki negatif yöndeki değişimin en büyük sebebinin tarım alanları olduğu saptanmıştır.

Anahtar kelimeler: Arazi kullanımı, Arazi Örtüsü, Düzce Illi

Submitted/Başvuru: 26.10.2020 • Revision Requested/Revizyon Talebi: 09.03.2021 • Last Revision Received Son Revizyon: 22.03 .2021 • Accepted/Kabul: 19.04.2021 Published Online/Online Yayın: 30.06.2021 


\section{INTRODUCTION}

Throughout the course of human history, people have benefited from nature and their land to survive (Garipağaoğlu and Duman, 2018). A land that is a geographical area; in addition to being a bio-productive natural entity under the functional influence of climate, soil, water, mineral substances and living things, it is a natural resource from which many things needed to sustain or facilitate life are produced (Özçağlar, n.d.). The lands that are part of the earth vary in terms of their cover layer and purpose. This diversity has led to the emergence of the concepts of "Land Use (LU)" and "Land Cover (LC)" (Sarı and Özşahin, 2016). Although these concepts are sometimes used interchangeably, they are essentially different (Anderson et al., 1976; Campbell, 1981; Di Gregorio and Jansen, 2000). Land cover is natural and human areas covering the earth act as a cover on which land use activities occur (Bayar, n.d.). In this context, vegetation cover, settlement cover and soil cover are the surface covers corresponding to the land cover (Coffey, 2013). On the other hand, is how people benefit from land use activities, arrangements, and inputs they perform on a certain type of land cover depends on the relationship between humans and the natural environment. It is the land management method according to social and economic purposes (Özçağlar, n.d.). In other words, land utilization determines the current use of the land in general, classification in terms of value and planning of the used style (Gözenç, 1980).

In the studies on land use and land cover, it is seen that these terms are not differentiated. In this respect, it would be appropriate to explain with an example the difference between the terms of land use (LU) and land cover (LC), which are sometimes used interchangeably. For example, a region as a nature park refers to land use, while coniferous forests within the nature park represent land cover. In short, land use shows how people use the land, whereas land cover shows the land's physical characteristics. Therefore, in this study where we consider the land cover and land use of Düzce province, the terms of land use (LU) and land cover (LC) were used as "LU/LC (Land Use/Land Cover)". These terms are used under a single heading in recent studies. Some of these studies are: Meyer and Turner II (1996), Fisher et al., (2005), Mark and Kudakwashe (2010), Gülersoy (2013, 2014), Hua et al., (2015), Karakuş et al., (2015), Sarı and Özşahin (2016), Altürk (2017), Kupkova et al., (2019), Brewington (2020).

It is necessary to plan land use and prevent past misuse to meet the increasing population's needs worldwide and use resources efficiently and sustainably. The development of settlements and industrial areas causes deterioration of agriculture, forest, pasture areas, and the lands' natural characteristics (Gülersoy, 2013: 170). In this respect, some studies and plans are conducted to make the best use of the land. An important part of these studies is the determination and analysis of past and present LU/LC. Today, satellite images are mostly used to make this determination. Thanks to the data obtained, various maps are presented and plans are made on them. Land cover maps provide information to help best understand the current situation. Land cover maps of different periods are needed to see the changes over time. In this context, the studies carried out using satellite images have developed considerably in the last half century. In these studies, geographical information systems are widely used in land classification and map production processes.

Various projects have been carried out at a regional, national and global scale in order to examine the change of land use and cover: National Land Cover Dataset in the USA, Countryside Survey in the UK, CORINE (Coordination of Information on the Environment) project that monitors the land cover and use of countries in Europe. In addition, the global scale International Land Use and Land Cover Change, International Geosphere Biosphere Program, Human Dimensions Program with Global Environmental Change and Global Environmental Change projects, including USGS land characterization.

The CORINE project was created in order to determine the change in land cover, to manage natural resources in the best way, to plan environmental policies and to obtain a standard database in all member countries of the European Environment Agency (EEA) (Ministry of Agriculture and Forestry, 2019). In the project created in line with the criteria and classification system determined by the European Environment Agency, the land cover data for the years 1990, 2000, 2006, 2012 and 2018 are included. Land cover characteristics are obtained by satellite images and various data sources (Karakaş Özür and Ataol, 2018). According to the criteria of the EEA and its system consisting of 44 classes, changes in the land cover for monitoring the land through satellite images are determined by using the RS (Remote Sensing) and GIS (Geographical Information Systems) (Ministry of Agriculture and Forestry, 2019).

The CORINE database is an essential resource for those who work on land cover and use, and this system is used in many studies conducted with remote sensing techniques (Bayar and Karabacak, 2017). The CORINE data system has begun to be used in geographers' studies on land cover and use, especially in 
recent years. Thus, Isparta (Başyiğit, 2004), Tekirdag (Sarı and Özşahin, 2016), Ankara (Bayar and Karabacak, 2017), Kilis (Karademir and Doğan, 2019), Mersin (Sandal et al., 2020) provinces, Thrace (Özdeş et al., 2019) and overall assessment studies (Karakas and Ataol, 2018; 2018) are the significant studies in Turkey that geographers have conducted by using the CORINE database. In addition, the number of studies conducted by geographers, earth and environmental scientists using the CORINE database in various parts of the world, especially in Europe, is increasing (Bossard et al., 2000; Janssen et al., 2008; Feranec et al., 2010; Pérez-Hoyos et al., 2012; Balzter et al., 2015; Grigorescu et al., 2018).

The purpose of the CORINE classification is to determine the degraded areas, the destroyed forest areas, the regions with low agricultural production, the distribution, and borders of permanent settlements (Başayiğit, 2004). In the study prepared in this respect, in order to use the land in a sustainable and more effective, the CORINE database was used to determine the change that occurred in LU/LC in Düzce province during the 28year period from 1990 to 2018 . This context aimed to draw attention to the improper land use in this period while considering the temporal change in Düzce province LU/LC classes between 1990, 2000 and 2018. Besides, determining the trend of the changes in LU/LC and contributing to the creation of sustainable land use policies in this direction are among the other objectives of the study. In this respect, it is thought that the study will contribute to regional planning and land monitoring systems.

\section{MATERIAL AND METHOD}

This study aimed to reveal land use changes and land cover in Düzce province using the CORINE system's data set. While the study was conducted, the CORINE land cover classes, which consist of 44 classes, were reduced to 7 classes by combining some land cover, taking into account the study area's characteristics (Table 1). In this context, determined the changes in Düzce province LU/LC in the 28-year period between 19902018. Land cover maps for the years 1990, 2000 and 2018 were recreated using the ArcGIS 10.4 program. The surface $\left(\mathrm{km}^{2}\right)$ of the changes occurring between these periods is presented, and the reasons and consequences of this change are emphasized. Besides, used the Land Use Capability (LUC) map of Düzce province to determine the areas suitable for agriculture and those that were not and the land cover maps of Düzce province for 1990, 2000 and 2018 overlapped with this map. Thus, it was determined in which class areas the change in land cover occurred according to the land use capability.
Table 1: Reclassification of CORINE land cover classes.

\begin{tabular}{ll}
\hline $\begin{array}{l}\text { Land Use / Land } \\
\text { Cover }\end{array}$ & $\begin{array}{l}\text { Its description within the CORINE land cover } \\
\text { classes }\end{array}$ \\
\hline Artificial Areas & $\begin{array}{l}\text { Continuous urban fabric, discontinuous urban fabric, } \\
\text { industrial or commercial units, road networks and } \\
\text { associated land, construction sites, sport and leisure } \\
\text { facilities }\end{array}$ \\
Agricultural Areas & $\begin{array}{l}\text { Non-irrigated arable land, permanently irrigated land, } \\
\text { fruit trees and berry plantations, complex cultivation } \\
\text { patterns }\end{array}$ \\
Forest Areas & $\begin{array}{l}\text { Broad-leaved forest, coniferous forest, mixed forest } \\
\text { Pasture Areas }\end{array}$ \\
Transitional & $\begin{array}{l}\text { Transitional woodland-shrub, land occupied } \\
\text { by agriculture, with significant areas of natural }\end{array}$ \\
Vegetation & $\begin{array}{l}\text { vegetation } \\
\text { Inland marshes } \\
\text { Beaches, dunes, sands, bare rocks, sparsely vegetated } \\
\text { areas }\end{array}$ \\
\hline
\end{tabular}

Also used TerrSet (IDRISI) software to reveal the changes in land cover in Düzce province. Using the land change model of the software (Land Change Modeler-LCM), the changes in the land cover of Düzce province in 1990, 2000 and 2018 and the direction of these changes were shown in the graphics. Also, a map was created with LCM to demonstrate how the land cover has changed between 1990-2018.

\subsection{Location, boundaries and general features of the study area}

Düzce province, which constitutes the study area, is located in the Western Black Sea Section of the Black Sea Region. Düzce province is adjacent to Zonguldak in the east and Bolu in the south. The province of Düzce is located in the west of Sakarya and surrounded by the Black Sea in the North (Figure 1).

Düzce province consists of the depression plain located in its center and the high area surrounding this plain. The plain floor, whose edges are limited by fault lines, constitutes the accumulation area within the depression trench, while the high area around the plain forms the erosive surfaces corresponding to the uplift area (Özdemir, 1992: 6). The province has a coast of approximately $30 \mathrm{~km}$ along the Black Sea in the north. Akçakoca Mountains rising behind the shore ends in the Düzce plain. The plain is surrounded by Keremali and Abant Mountains in the south and Bolu Mountains in the east. In comparison, Düzce plain's elevation ranges between 130-180 meters, the elevation level increases in the surrounding mountainous area and is higher than 1500 meters in the south (Figure 2).

Düzce Plain, which is in the form of bottomland, presents high seismicity due to its geological structure. Düzce, Hendek 


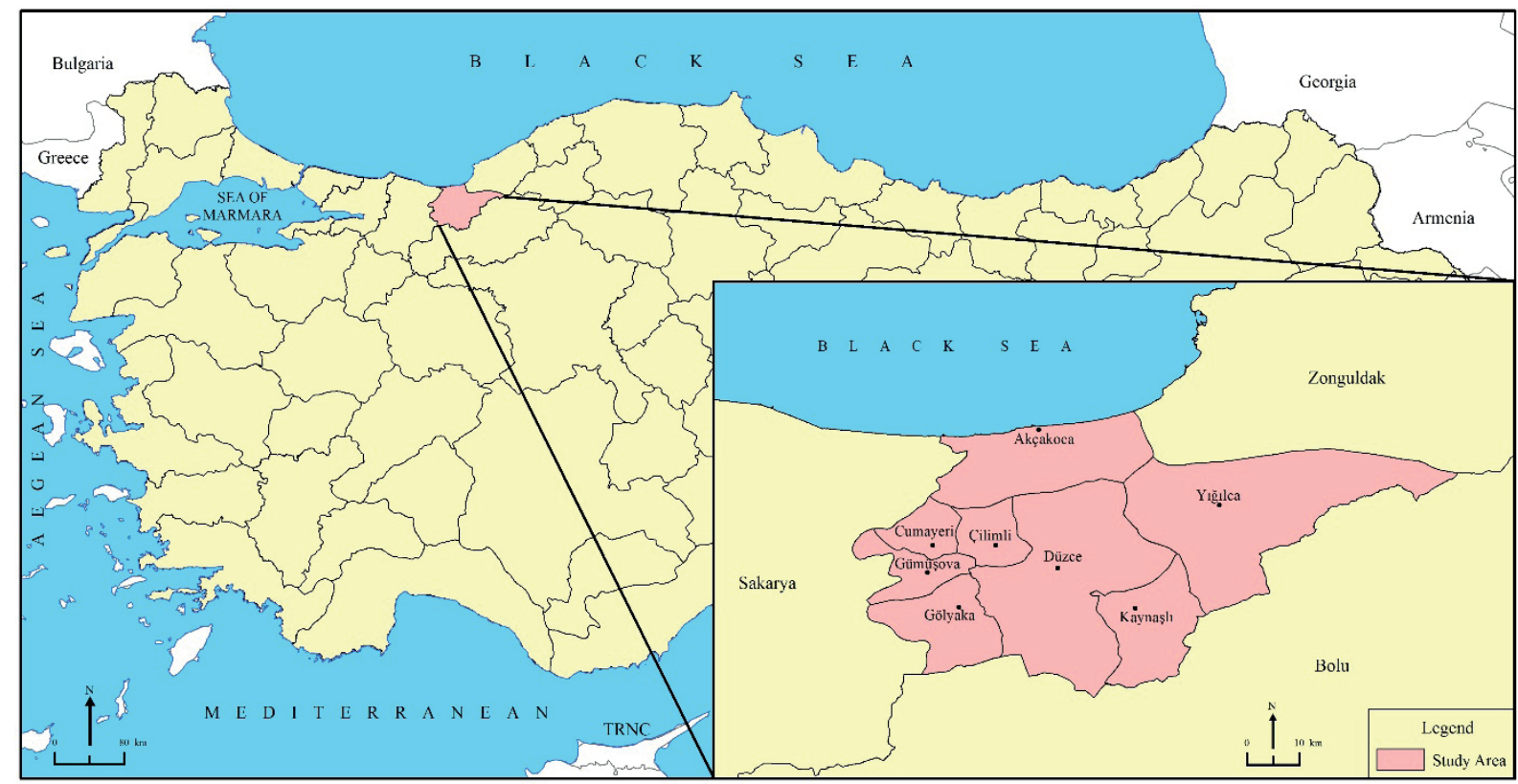

Figure 1: Location map of study area.

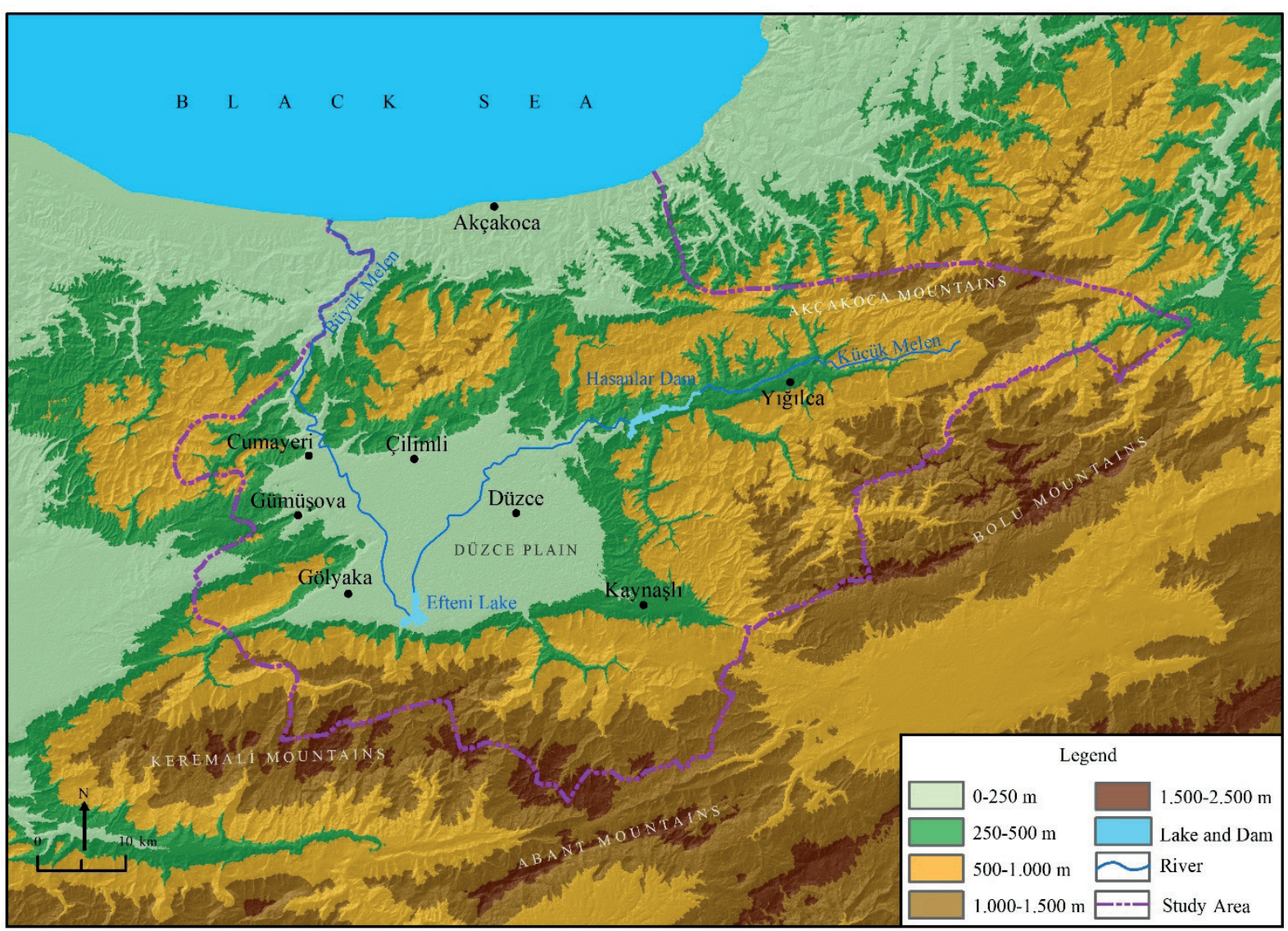

Figure 2: Morphometric map of Düzce province and its near area.

and Çilimli active faults, which are part of the North Anatolian Fault Zone, are located in the Düzce Plain and its immediate surroundings. Therefore, the settlements in the region have been under the destructive effect of these faults from time to time. It was particularly affected by the earthquakes that took place on 17 August and 12 November 1999. In these earthquakes, 
extensive damage occurred in the administrative center of Kaynaşlı, Gölyaka and Düzce, which led to changes in land use.

Among the lakes in Düzce province, the lake with the largest surface area is Efteni Lake, located in the northwest of Düzce plain. The rivers in the region are included in the Melen Basin, a sub-basin of the Western Black Sea Basin. The two most important rivers within the provincial borders are Büyük Melen and Küçük Melen. Hasanlar Dam is located on Küçük Melen, which takes its source within the borders of Yığılca district. Büyük Melen, which takes its source from Efteni Lake, flows towards the north and drains its waters into the Black Sea from Melenağzı village located on the Sakarya-Düzce provincial border. Büyük Melen was included in the Büyük Melen Project in 1997 and it was decided to build a dam on it. The Melen Dam, which is under construction situated $7 \mathrm{~km}$ west of the Büyük Melen River will meet some of İstanbul's water needs and start hydroelectric production after its completion.

The Black Sea climate is dominant throughout the study area. While these conditions are more pronounced in the coastal area, we can see differences towards the inner parts. As a matter of fact, in Akçakoca, which is located on the Black Sea coast in the north, the annual precipitation is $1080 \mathrm{~mm}$. The highest precipitation season is autumn, while the annual precipitation in Düzce city center is $831 \mathrm{~mm}$ and the highest rains in winter (Siyanuş, 2013: 73-74). The annual average temperature in Düzce is $13{ }^{\circ} \mathrm{C}$ (Figure 3). The climatic characteristics prevailing throughout the province affect LU/LC. This situation affects agricultural activities as well as the characteristics and distribution of vegetation. The hazelnut, which is grown in various provinces on the Black Sea coast, is also common in Düzce. However, hazelnut agriculture is mostly carried out in

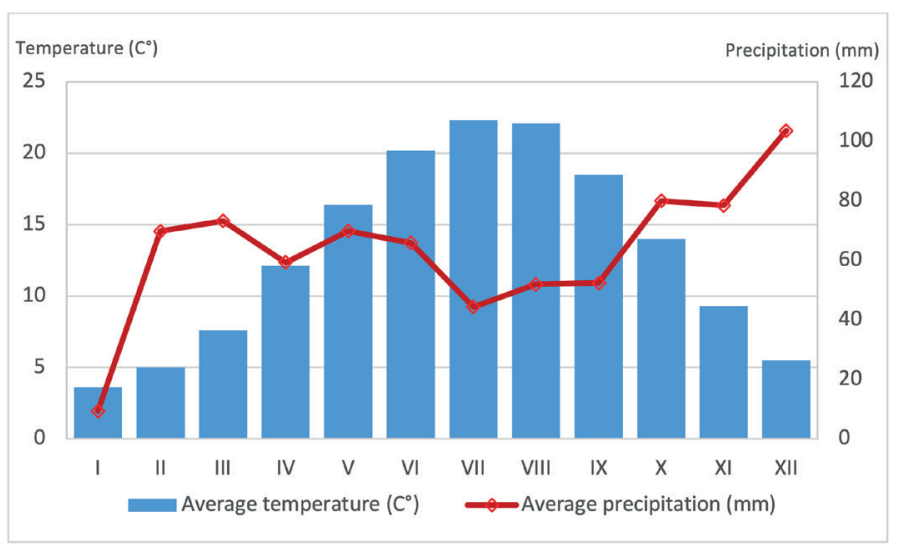

Figure 3: Change of temperature and precipitation by months in the province of Düzce (1959-2019), (Turkish State Meteorological Service, 2020).
Akçakoca because of climate, land structure and soil type. In the inner parts, corn, wheat and paddy are cultivated besides hazelnuts.

The distribution of human activities and land cover classes are closely related to the distribution of soil groups. The most common soil group within Düzce province's borders, which constitutes the study area, is the Limeless Brown Forest soils. These soils, which are generally deciduous in winter and spread in broad-leaved forests, are seen in the mountainous areas around the Düzce plain. Another soil group with a wide distribution area in the study area dominated by the Black Sea climate is the Red Yellow Podzolic soils. The Red Yellow Podzolic soils on the Black Sea coast spread from the coastal area to the Düzce plain. Alluvial soils suitable for agriculture are present in almost all of Düzce plain. In contrast, Brown Forest soils are observed in the forest area in the east of the province and Gray Brown Podzolic soils roughly in the northeast. Apart from these, hydromorphic and colluvial soils are found in the form of thin strips in places (Figure 4, Table 2).

Another factor affecting the distribution of $\mathrm{LU} / \mathrm{LC}$ is the area and distribution of Land Use Capability (LUC) classes. In this respect, those in the first four LUC classes constitute the areas suitable for cultivated agriculture. In comparison, the areas in the last four classes represent ones not suitable for cultivated agriculture. Fifth, sixth, and seventh-class lands, which are not suitable for agriculture, could be opened for cultivation from time to time. This situation causes erosion, and bedrock comes to the surface, lands turn into eighth-class useless lands (Gülersoy, 2014:61). These lands should be used as pasture and forest. Besides, eighth-class lands create a life for the natural environment and can be used for various activities such as tourism and sports. When Düzce province lands are considered in terms of land use capability, while $21 \%$ of the land is suitable for cultivated agriculture, $79 \%$ constitutes areas not suitable for cultivated agriculture (Table 3). Most of the lands suitable for cultivated agriculture in Düzce province are located in the Düzce plain and its immediate surroundings. Apart from this, there are lands around Akçakoca in the north that are suitable for cultivated agriculture. Soils that are not suitable for cultivated agriculture are found in high and sloping fields around the Düzce plain (Figure 5).

Whereas Düzce, which constitutes the study area, was a district of Bolu province until 1999, it gained a province's status (as of 81 st province of Turkey) after this date due to the earthquake 17 august 1999. Düzce province, which has an area of 


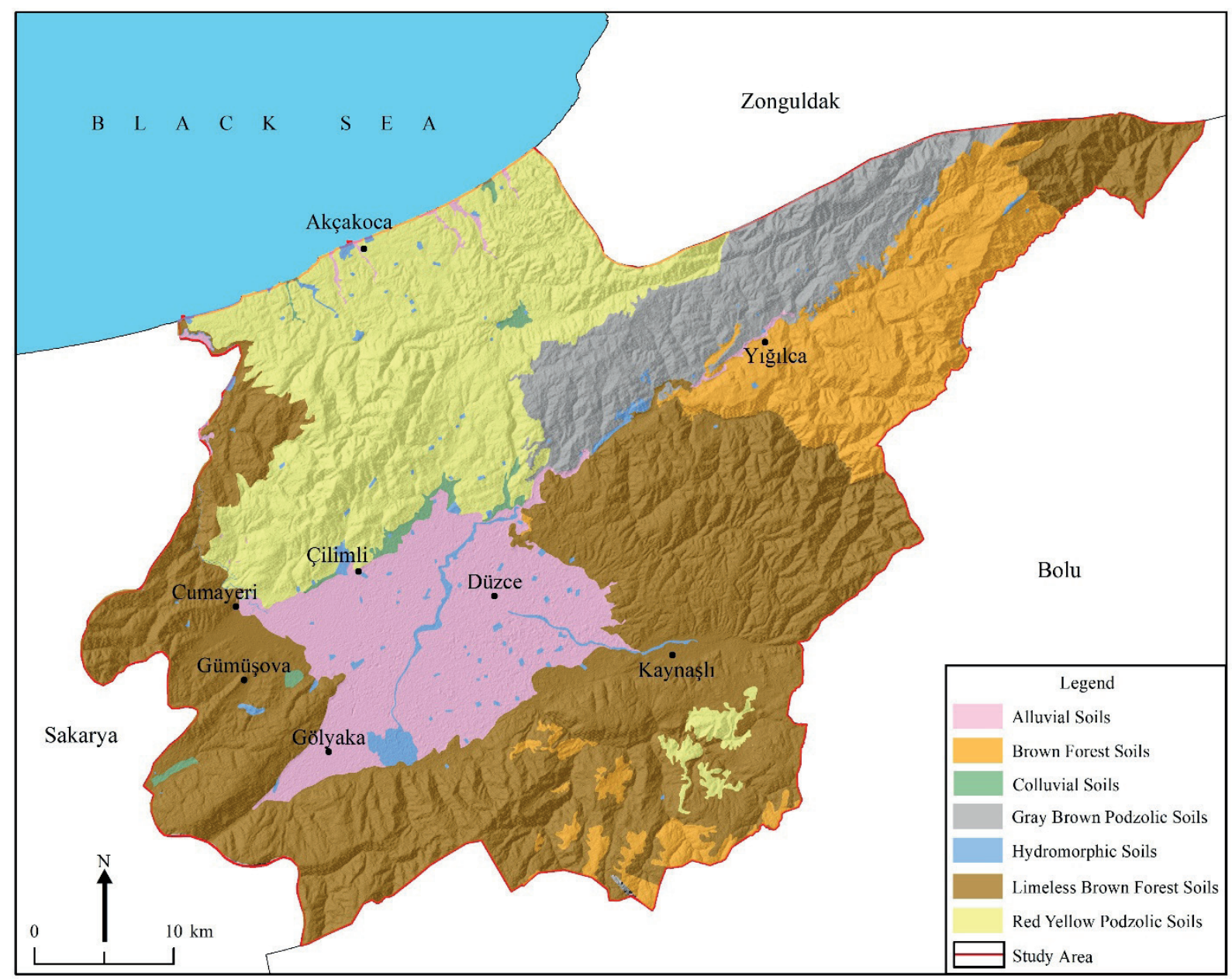

Figure 4. Soil groups map of study area (Republic of Turkey Ministry of Agriculture and Forestry, 2013).

Table 2: Soil groups of Düzce province (Republic of Turkey Ministry of Agriculture and Forestry, 2013).

\begin{tabular}{lcc}
\hline Soil Groups & Field $\left.\mathbf{( k m}^{\mathbf{2}}\right)$ & Rate $(\%)$ \\
\hline Limeless Brown Forest Soils & 1080 & 43 \\
Red Yellow Podzolic Soils & 550 & 22 \\
Alluvial Soils & 294 & 12 \\
Brown Forest Soils & 289 & 12 \\
Gray Brown Podzolic Soils & 233 & 9 \\
Hydromorphic Soils & 13 & 1 \\
Colluvial Soils & 18 & 1 \\
Total & 2,477 & 100 \\
\hline
\end{tabular}

approximately 2,477 $\mathrm{km}^{2}$, consists of 8 districts including Akçakoca, Cumayeri, Çilimli, Gölyaka, Gümüşova, Kaynaşlı, Yı̆̆ılca and Merkez districts. Besides, there are 114 neighborhoods and 278 villages together with Beyköy and Boğaziçi towns within the province. Transportation has an important place in the development of Düzce, which is located at the transition point between cities such as İstanbul, Kocaeli, Sakarya, Ankara and Zonguldak, where industrial activities are carried out. In addition to industrial establishments, agriculture, forestry products, trade
Table 3: Land classes surfaces of Düzce province (Republic of Turkey Ministry of Agriculture and Forestry, 2013).

\begin{tabular}{lc}
\hline Land Class & Surface $\left.\mathbf{( k m}^{\mathbf{2}}\right)$ \\
\hline Class I & 270 \\
Class II & 61 \\
Class III & 48 \\
Class IV & 116 \\
Class V & 8 \\
Class VI & 290 \\
Class VII & 1,665 \\
Class VIII & 19 \\
Total & 2,477 \\
\hline
\end{tabular}

and service sectors constitute other economic activities. While the Düzce province population in 1990 was 273,679, it increased to 314,266 in 2000 with an annual increase rate of $1.5 \%$ depending on fertility and immigration. Although the 1999 earthquake and the emigrations slowed down the annual population growth rate to $1.3 \%$, the population continued to increase, growing to 387,844 in 2018. To meet the increasing population's needs, the areas allocated to socio-economic activities have expanded, leading to land use changes. 


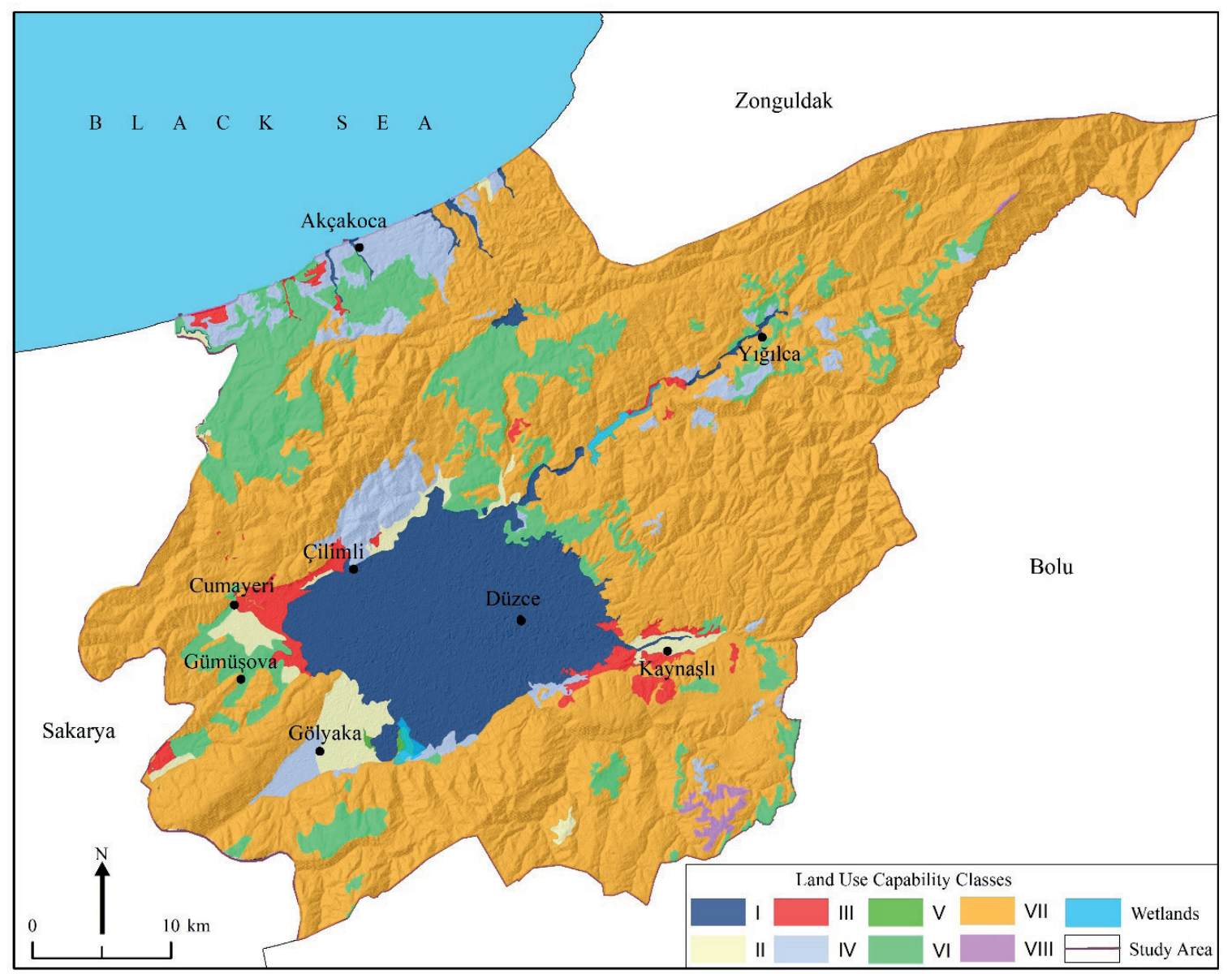

Figure 5. Map of land use capability classes of Düzce province (Republic of Turkey Ministry of Agriculture and Forestry, 2013).

\section{FINDINGS}

\subsection{Land use and land cover change in 1990}

In this study, in which the examined change of LU/LC in Düzce province using the CORINE database, the data of 1990 on LU/LC was used as base data. In the province of Düzce, which has approximately $2477 \mathrm{~km}^{2}$, the largest land cover to this date is forests. The forest cover seen in the mountainous area surrounding the Düzce plain covers $1,489 \mathrm{~km}^{2}$ and covers approximately $60 \%$ of the provincial acreage (Table 4). The forest cover

Table 4: Land use/land cover rates of Düzce province (1990).

\begin{tabular}{lcc}
\hline LU/LC & Surface $\left.\mathbf{( k m}^{\mathbf{2}}\right)$ & Rate \\
\hline Artificial Areas & 38.8 & 1.6 \\
Agricultural Areas & 679.2 & 27.4 \\
Forest Areas & 1488.4 & 60.1 \\
Pasture Areas & 19.7 & 0.8 \\
Transitional vegetation & 240.9 & 9.7 \\
Wetlands & 6.2 & 0.3 \\
Other Areas & 3.5 & 0.1 \\
Total & 2476.8 & 100 \\
\hline
\end{tabular}

consists of broad-leaved, coniferous and mixed forests that form the region's characteristic vegetation.

With $679 \mathrm{~km}^{2}$, the largest land cover after the forest belongs to agricultural areas. Agricultural lands covering 27.4\% of Düzce province consist of non-irrigated arable lands, irrigated agricultural lands, orchards and mixed farming areas. An important part of the agricultural area is located in the Düzce plain. It is seen in the coastal areas and the northeast, south and southwest of the province. Transitional vegetation within the LU/LC classes forms the vegetation change formed due to deforestation and the land cover occupied by agricultural land. The LU/LC belonging to the transitional vegetation, spread over approximately $241 \mathrm{~km}^{2}$, occupies $9.7 \%$ of the total area. Transitional vegetation areas are generally seen in transition areas between forest and agricultural areas.

Continuous city structure, non-urban structure, industrial and commercial units, highways, construction areas, sports and recreation areas constitute LU/LC, classified as artificial areas in 
Düzce province. Artificial areas covering approximately $39 \mathrm{~km}^{2}$ constitute $1.6 \%$ of the provincial area (Figure 6). The residential area, which has the largest area among the artificial areas, belongs to the urban of Düzce and covers $24 \%$ of the artificial areas. The urban of Akçakoca follows it with 9\%. Pasture areas are also another area of the LU/LC classes in the study area. It represents $0.8 \%$ of the LU/LC classes of the grasslands spread over an area of $20 \mathrm{~km}^{2}$. Other areas belonging to LU/LC are wetlands representing lakes and dams with coastal, beach, sparse vegetation, and bare areas. Efteni Lake and Hasanlar Dam constitute an important part of the wetlands. The area covered by wetlands and other areas in LU/LC is less than $1 \%$.

In order to reveal the distribution of land use on arable and non-arable lands in the province of Düzce, LUC and LU/LC classes were overlapped. Accordingly, $362 \mathrm{~km}^{2}$ of the land suitable for cultivation agriculture is reserved for agriculture. This amount corresponds to approximately $73 \%$ of the lands suitable for cultivated agriculture, approximately $495 \mathrm{~km}^{2}$ (Table 5). Apart from of the areas suitable for agriculture, $12 \%$ are forests, $5.9 \%$ are artificial areas, and $5.8 \%$ are transitional vegetation. Of the approximately $1982 \mathrm{~km}^{2}$ land that is not
Table 5: Distribution of Düzce province land classes by land use/ land cover in 1990.

\begin{tabular}{lcccc}
\hline \multirow{2}{*}{ LU/LC } & \multicolumn{4}{c}{ Land Use Capability } \\
\cline { 2 - 5 } & I-IV (km $\left.\mathbf{~}^{\mathbf{2}}\right)$ & Rate (\%) & V-VIII $\mathbf{( k m}^{\mathbf{2}}$ ) & Rate (\%) \\
\hline Artificial Areas & 29 & 5.9 & 9.8 & 0.5 \\
Agricultural Areas & 362.2 & 73.2 & 317 & 16 \\
Forest Areas & 59.5 & 12 & 1429 & 72.1 \\
Pasture Areas & 10.4 & 2.1 & 9.3 & 0.5 \\
Transitional vegetation & 28.9 & 5.8 & 212 & 10.7 \\
Wetlands & 1 & 0.2 & 2.5 & 0.1 \\
Other Areas & 3.8 & 0.8 & 2.4 & 0.1 \\
Total & 494.8 & 100 & 1982 & 100 \\
\hline
\end{tabular}

suitable for cultivated agriculture, $1,429 \mathrm{~km}^{2}$ consists of forest cover. Accordingly, $72 \%$ of the areas not suitable for agriculture are forest cover. Because of the prevalence of high and sloping lands throughout Düzce province, except the Düzce plain, some non-suitable areas for cultivation are used for agricultural activities. This may occur especially in areas where hazelnut agriculture is carried out. In this respect, agricultural areas occupy $16 \%$ of the areas not suitable for agriculture in the study area. The ratio of the areas belonging to transitional vegetation cover, generally between forest and agricultural areas, is not

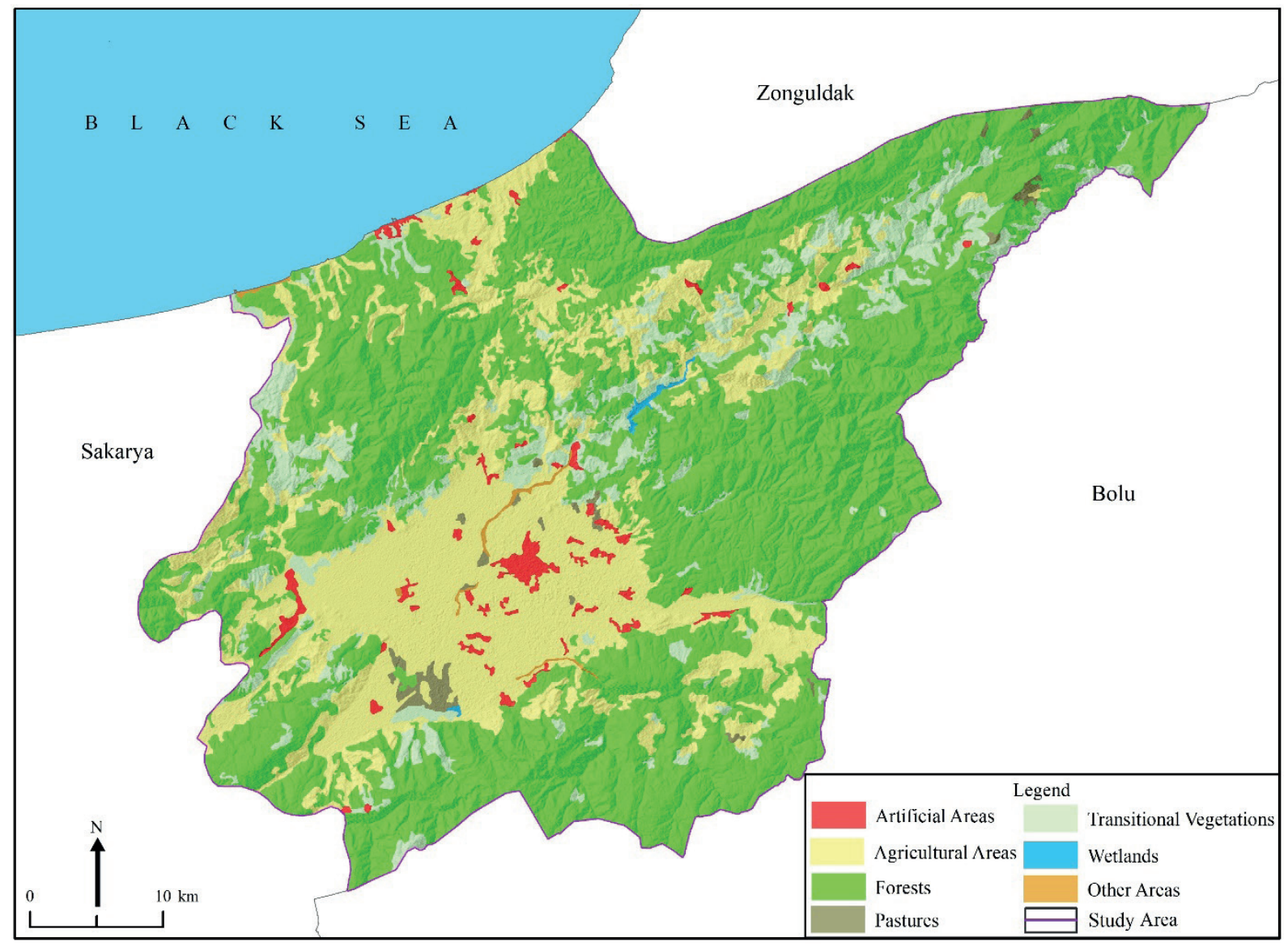

Figure 6: Land use/land cover map of Düzce province in 1990. 
suitable for agriculture, which is $10.7 \%$. Aside from the mentioned areas, the area covered by the classes belonging to $\mathrm{LU} / \mathrm{LC}$ that is not suitable for agriculture is below $1 \%$.

\subsection{Land use and land cover change in 2000}

When the distribution of LU/LC in Düzce province is examined for the year 2000, it is seen that there are no significant changes compared to 1990. In contrast to the previous period, the class that expands its area the most belongs to the forest cover with a growth of $55 \mathrm{~km}^{2}$. Artificial areas follow it with $17.5 \mathrm{~km}^{2}$. In 2000, the land covers with the highest contraction among the LU/LC classes compared to 1990 belonged to transitional vegetation with a decrease of approximately $60 \mathrm{~km}^{2}$ and agricultural areas with $13 \mathrm{~km}^{2}$. The change in other LU/LC classes is less (Table 6, Figure 7).

Generally, in studies conducted in recent years, it is observed that the agricultural areas have increased, and the areas belonging to forest cover are gradually decreasing. However, in the province of Düzce, the situation between 1990-2000 took place in the opposite direction. The reason for that is the forest and cadastral works carried out by the Düzce Forestry Operation Directorate during this period. In this context, the areas that were previously converted to agricultural land from forest land were determined. Later, saplings were planted in these areas and turned back into forest land. Besides, carried out works in transitional vegetation areas. As a result of these works, the proportion of forest areas within the total LU/LC increased by $2 \%$ compared to the previous period and reached $62.3 \%$. The ratio of agricultural lands decreased by $0.5 \%$ and its share in the total ratio decreased to $27 \%$ approximately. The other LU/LC class, which expanded its area in 2000 compared to the previous period, belongs to artificial areas (Figure 8). With the increase of the population from approximately 273,676 in 1990 to 314,679 in 2000, the settlement area has expanded. The largest settlement area in the artificial areas in 2000 was Düzce city, which was spread over an area of $10 \mathrm{~km}^{2}$, followed by Akçakoca city with $3.5 \mathrm{~km}^{2}$ as in 1990 . Besides, the area covered by artificial areas increased with the start of operation in 1992 of the Anatolian Highway, which connects İstanbul to Ankara, within Düzce. Besides, the opening of Düzce OIZ (Organized Industrial Zone) in 1996 expanded these areas.

In $2000,70.7 \%$ of the land suitable for cultivated agriculture in the study area was allocated to the agricultural area. It was followed by forest with $14 \%$ and artificial areas with $8.6 \%$ (Table 7). Artificial areas increased the area they covered on suitable land for agriculture from 1990 to 2000 . There has been a decrease in areas belonging to agriculture, forestry, pasture and transitional vegetation. In areas that are not suitable for cultivated agriculture, as in 1990, the largest LU/LC belongs to forest areas

Table 6: Land use/land cover change of Düzce province (1990-2000).

\begin{tabular}{|c|c|c|c|c|}
\hline \multirow{2}{*}{ LU/LC } & \multirow{2}{*}{ Surface $\left(\mathbf{k m}^{2}\right)$} & \multirow{2}{*}{ Rate (\%) } & \multicolumn{2}{|c|}{ Increase / Decrease } \\
\hline & & & Surface $\left(\mathbf{k m}^{2}\right)$ & Field $\left(\mathbf{k m}^{2}\right)$ \\
\hline Artificial Areas & 56.3 & 2.3 & 17.5 & 0.7 \\
\hline Agricultural Areas & 665.8 & 26.9 & -13.4 & -0.5 \\
\hline Forest Areas & 1543.5 & 62.3 & 55.1 & 2.2 \\
\hline Pasture Areas & 18.5 & 0.8 & -1.2 & -0.1 \\
\hline Transitional vegetation & 181.3 & 7.2 & -59.6 & -1.5 \\
\hline Wetlands & 5.1 & 0.2 & -1.1 & -0.1 \\
\hline Other Areas & 6.3 & 0.3 & 2.8 & 0.2 \\
\hline Total & 2476.8 & 100 & - & - \\
\hline
\end{tabular}

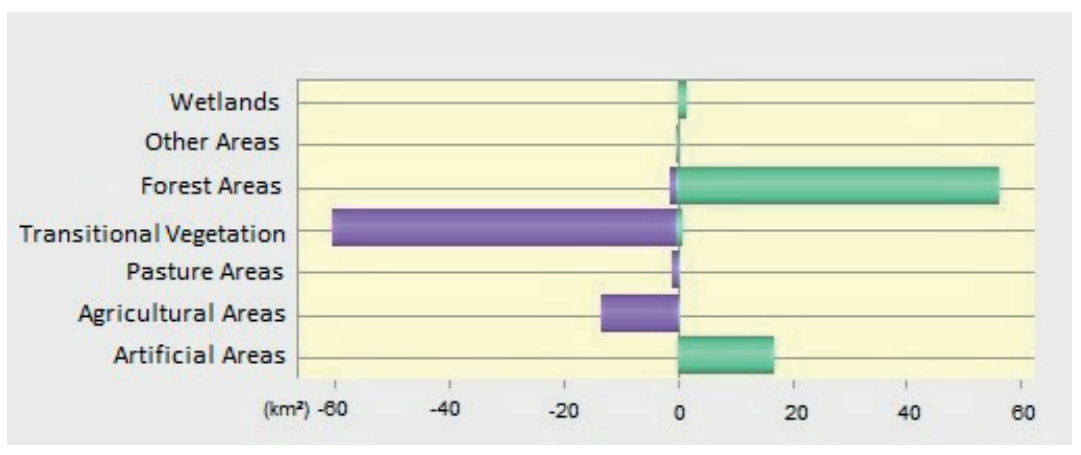

Figure 7. Gains and losses in Düzce province land use/land cover (1990-2000) 


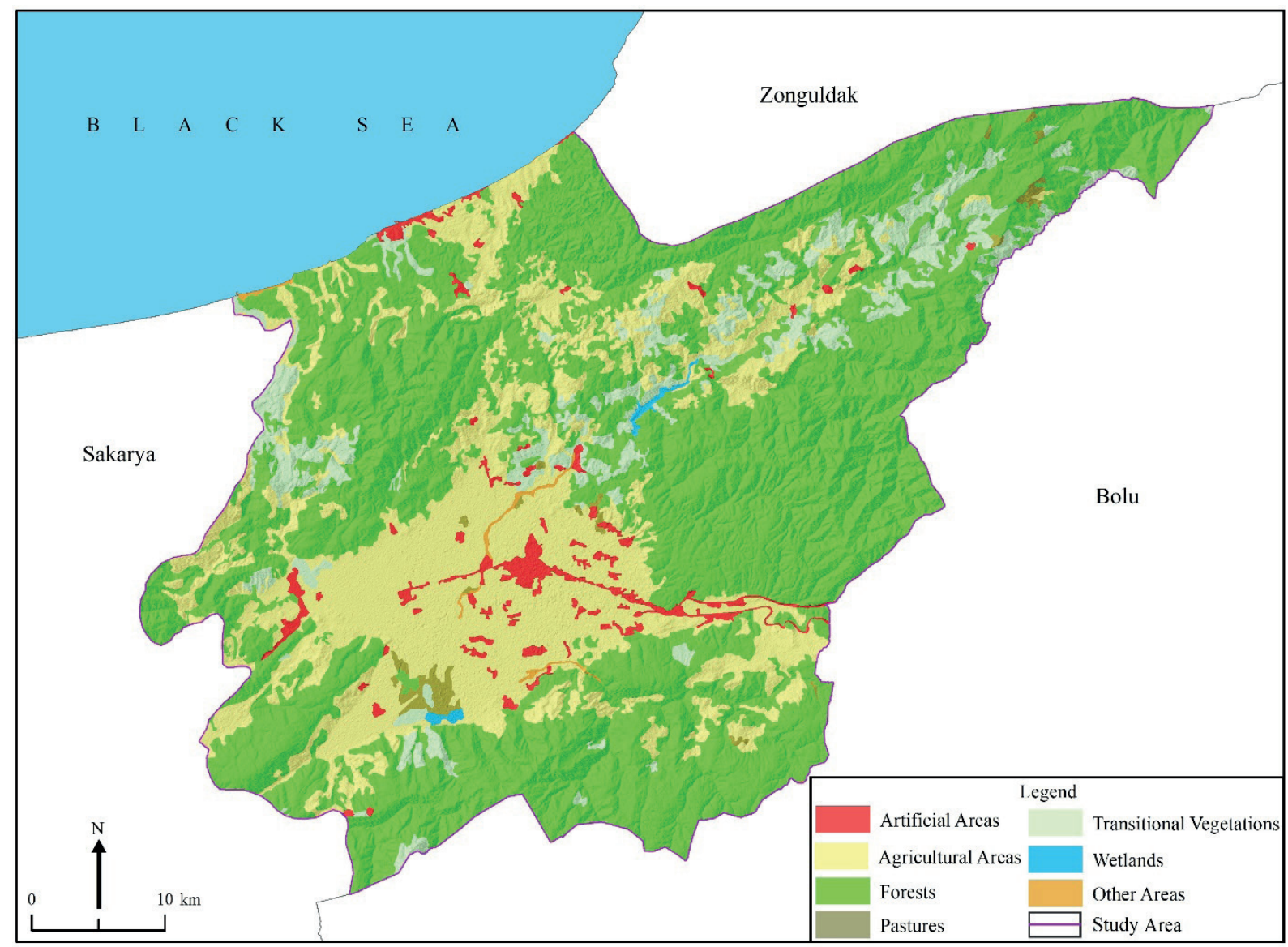

Figure 8. Land use/land cover map of Düzce province in 2000

Table 7: Distribution of Düzce province land classes by land use/ land cover in 2000.

\begin{tabular}{|c|c|c|c|c|}
\hline \multirow{2}{*}{ LU/LC } & \multicolumn{4}{|c|}{ Land Use Capability } \\
\hline & I-IV $\left(\mathbf{k m}^{2}\right)$ & Rate (\%) & V-VIII $\left(\mathbf{k m}^{2}\right)$ & Rate (\%) \\
\hline Artificial Areas & 42.7 & 8.6 & 13.6 & 0.7 \\
\hline Agricultural Areas & 349.8 & 70.7 & 316 & 15.9 \\
\hline Forest Areas & 68.9 & 13.9 & 1474.1 & 74.4 \\
\hline Pasture Areas & 9 & 1.9 & 9.5 & 0.5 \\
\hline Transitional vegetation & 18.9 & 3.8 & 162.4 & 8.2 \\
\hline Wetlands & 2 & 0.4 & 3.6 & 0.2 \\
\hline Other Areas & 3.5 & 0.7 & 2.8 & 0.1 \\
\hline Total & 494.8 & 100 & 1982 & 100 \\
\hline
\end{tabular}

with $74.4 \%$. The proportion of agricultural lands in areas that are not suitable for agriculture is about $16 \%$, while the rate of transitional vegetation areas is $8.2 \%$.

\subsection{Land use and land cover change in 2018}

Significant changes occurred in the province of Düzce in 2018 in LU/LC compared to the previous period, 1990-2000. Especially, the earthquake that occurred in 1999 has caused changes in land use practices. Besides, new areas have been opened for reconstruction in Düzce, a province to heal the earthquake's consequences. Over the last 18 years, the area covered by agricultural and artificial lands has expanded. Accordingly, an increase of $397 \mathrm{~km}^{2}$ in agricultural areas and its ratio within the total $\mathrm{LU} / \mathrm{LC}$ classes has increased from approximately $27 \%$ to $43 \%$. Especially, while a significant part of the area between Düzce plain and the coastal area was previously composed of forest cover, it is seen that a significant part of it turned into agricultural land in 2018 (Figure 9). Again, areas belonging to the forest and transitional vegetation in the west, northwest and northeast of the province have also turned into agricultural areas.

It is seen that artificial areas have expanded compared to the previous period. In this period of time, the artificial areas expanded by $35 \mathrm{~km}^{2}$ and reached $91 \mathrm{~km}^{2}$. Thus, the ratio of artificial areas within the LU/LC classes increased to $3.7 \%$. Socio-economic needs have increased with the Düzce province population, which was from 314,266 in 2000 to 387,847 in 2018. In order to meet these needs, artificial areas have 


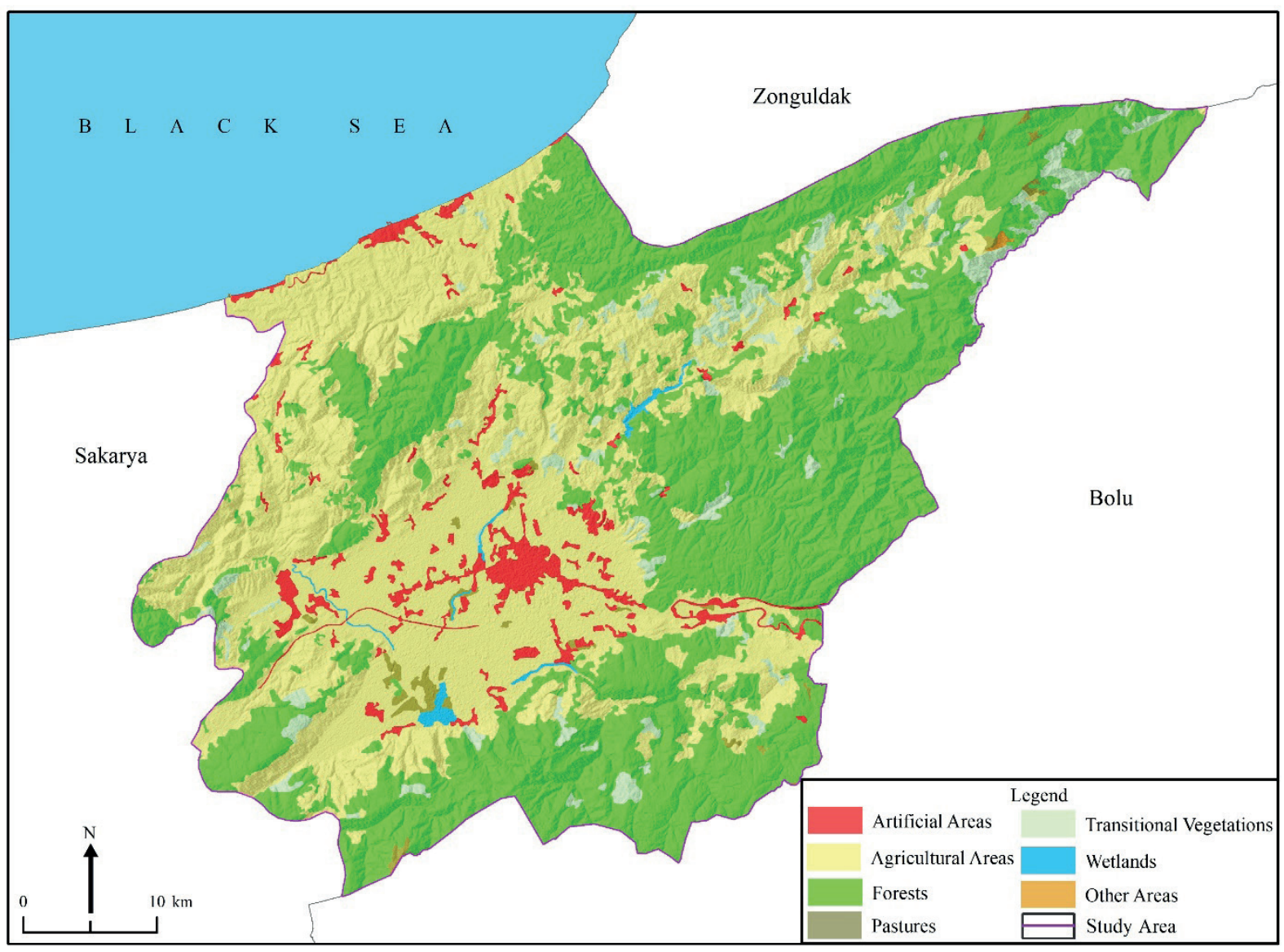

Figure 9: Land use/land cover map of Düzce province in 2018.

expanded. In 2000, the urban area of Düzce reached $18 \mathrm{~km}^{2}$ as a result of rapid urban expansion. After the earthquakes that occurred in 1999 and Düzce gained the status of a province, the new residential areas formed on the periphery of the city and the establishment of Düzce University in 2006 caused the expansion of artificial areas. Bahçeşehir (Kalıcı Konutlar) area, which is located in the northeast of the city and is approximately $3 \mathrm{~km}$ away from the city centre, has become a residential area that developed after the earthquake. With Düzce becoming a province, a population of 25,000 resides in an area of approximately $6 \mathrm{~km}^{2}$, which was opened to construction. In addition to this, the increase in the number of the small industrial zone in the vicinity of the city and the number of organizations within the OIZ, developments in the metal, machinery, automotive, textile, and forestry products sectors have caused the expansion of the artificial areas. Another land cover that expanded its area within the LU/LC classes in 2018 is wetlands. In 2014, it was decided by the National Wetland Commission to double the current state of the lake surface within the scope of the "Efteni Lake Wetland Management Plan" (Ministry of Forestry and Water Affairs Düzce
Development Plan, 2019). As a result of the related study, there has been an expansion of approximately $5 \mathrm{~km}^{2}$ in the wetland surface of Düzce province.

In the province of Düzce, contraction occurred between 2000-2018 in the forest, transitional vegetation, other areas and pasture areas among the LU/LC classes. Among these areas, the highest loss occurred in forest areas with $357 \mathrm{~km}^{2}$, and its ratio within LU/LC classes decreased from approximately $62 \%$ to 48\% (Table 8, Figure 10). Again, in areas belonging to transitional vegetation, a decrease of $76 \mathrm{~km}^{2}$ occurred, and its ratio within the total $\mathrm{LU} / \mathrm{LC}$ classes decreased from $7.2 \%$ to $4.3 \%$. As stated before, the reason for the losses in these areas is agricultural and settlement areas.

When the distribution of the LU/LC area in 2018 is interpreted in terms of the land use capability, it is seen that the rate of agricultural lands among the lands suitable for cultivated agriculture increased to $78.5 \%$ compared to the previous period (Table 9). Artificial areas follow again with $14.4 \%$. Apart from these two mentioned LU/LC, it is observed 
Table 8: Land use/land cover change of Düzce province (2000-2018).

\begin{tabular}{|c|c|c|c|c|}
\hline \multirow{2}{*}{ LU/LC } & \multirow{2}{*}{ Surface $\left(\mathbf{k m}^{2}\right)$} & \multirow{2}{*}{ Rate (\%) } & \multicolumn{2}{|c|}{ Increase / Decrease } \\
\hline & & & Surface $\left(\mathbf{k m}^{2}\right)$ & Rate (\%) \\
\hline Artificial Areas & 91.2 & 3.7 & 34.9 & 1.4 \\
\hline Agricultural Areas & 1062.6 & 42.9 & 396.8 & 16 \\
\hline Forest Areas & 1186.8 & 479 & -356.7 & -14.4 \\
\hline Pasture Areas & 18.4 & 0.7 & -0.1 & -0.1 \\
\hline Transitional vegetation & 105.4 & 4.3 & -75.9 & -2.9 \\
\hline Wetlands & 11 & 0.4 & 5.9 & -0.2 \\
\hline Other Areas & 1.4 & 0.1 & -4.9 & 0.2 \\
\hline Total & 2476.8 & 100 & - & - \\
\hline
\end{tabular}

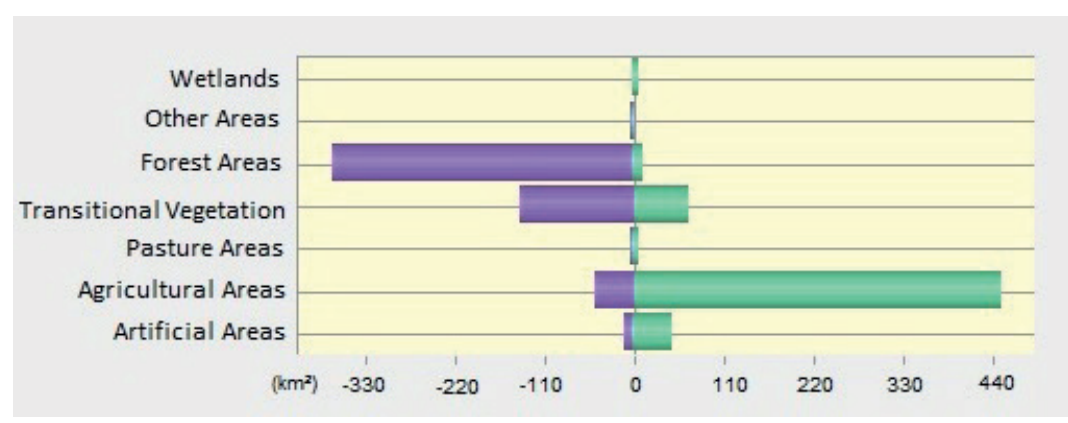

Figure 10: Gains and losses in Düzce province land use/land cover (2000-2018).

Table 9: Distribution of Düzce province land classes by land use/ land cover in 2018.

\begin{tabular}{|c|c|c|c|c|}
\hline \multirow{2}{*}{ LU/LC } & \multicolumn{4}{|c|}{ Land Use Capability } \\
\hline & I-IV $\left(\mathbf{k m}^{2}\right)$ & Rate (\%) & V-VIII $\left(\mathbf{k m}^{2}\right)$ & Rate (\%) \\
\hline Artificial Areas & 71 & 14.4 & 20.2 & 1 \\
\hline Agricultural Areas & 388.2 & 78.5 & 674.4 & 34 \\
\hline Forest Areas & 18 & 3.6 & 1168.8 & 59 \\
\hline Pasture Areas & 8.8 & 1.8 & 9.6 & 0.5 \\
\hline Transitional vegetation & 3.2 & 0.6 & 102.2 & 5.1 \\
\hline Wetlands & 5.2 & 1 & 5.8 & 0.3 \\
\hline Other Areas & 0.4 & 0.1 & 1 & 0.1 \\
\hline Total & 494.8 & 100 & 1982 & 100 \\
\hline
\end{tabular}

that other LU/LC areas suitable for agriculture have decreased. As before, forests cover the largest area of land that is not suitable for cultivated agriculture. However, it is seen here that the forest cover has decreased and the agricultural areas have increased compared to the previous period. The reason for this is that after the areas suitable for agriculture are filled with agriculture and artificial areas, agricultural activities are tried to carry out in areas that are not suitable for agriculture to meet the need.

Compared to the distribution of LU/LC in the study area in 1990 and 2018, a transformation that occurred within the LU/LC classes during this period was discussed. The forests covered the largest area in 1990 and 2018 (Table 10, Figure 11). However, a
Table 10: Land use/land cover change of Düzce province (1990-2018).

\begin{tabular}{lcccc}
\hline \multirow{2}{*}{ LU/LC } & \multicolumn{2}{c}{ Surface $\left.\mathbf{( k m}^{2}\right)$} & \multicolumn{2}{c}{ Increase / Decrease } \\
\cline { 2 - 5 } & In $\mathbf{1 9 9 0}$ & In $\mathbf{2 0 1 8}$ & Surface $\left.\mathbf{( k m}^{2}\right)$ & Rate (\%) \\
\hline Artificial Areas & 38.8 & 91.2 & 52.4 & 7.5 \\
Agricultural Areas & 679.2 & 1062.6 & 383.4 & 3.1 \\
Forest Areas & 1488.4 & 1186.8 & -301.6 & -1.2 \\
Pasture Areas & 19.7 & 18.4 & -1.3 & -0.4 \\
Transitional Vegetation & 240.9 & 105.4 & -135.5 & -3.1 \\
Wetlands & 6.2 & 11 & 4.8 & 4.3 \\
Other Areas & 3.5 & 1.4 & -2.1 & 3.3 \\
Total & 2476.8 & 2476.8 & - & - \\
\hline
\end{tabular}

loss of approximately $302 \mathrm{~km}^{2}$ occurred in areas belonging to forest cover compared to 1990. This is because forest cover is occupied by agriculture, transitional vegetation and artificial areas. Approximately $267 \mathrm{~km}^{2}$ of forest cover areas have been turned into agricultural land, $30 \mathrm{~km}^{2}$ transitional vegetation, 4 $\mathrm{km}^{2}$ artificial land, and $1 \mathrm{~km}^{2}$ pasture. It is understood that the main reason for the destruction of forests is land clearing. Various studies were carried out in the region by the Ministry of Agriculture and Water Affairs regarding this issue. Occupied lands are transformed back into forests with cadastral works carried out in this context. Besides, carried out afforestation maintenance and rehabilitation works in $6.5 \mathrm{~km}^{2}$ area, afforestation in an area of $30 \mathrm{~km}^{2}$ between 2014-2018 (Ministry of Forestry and Water Affairs Düzce Development Plan, 2014- 


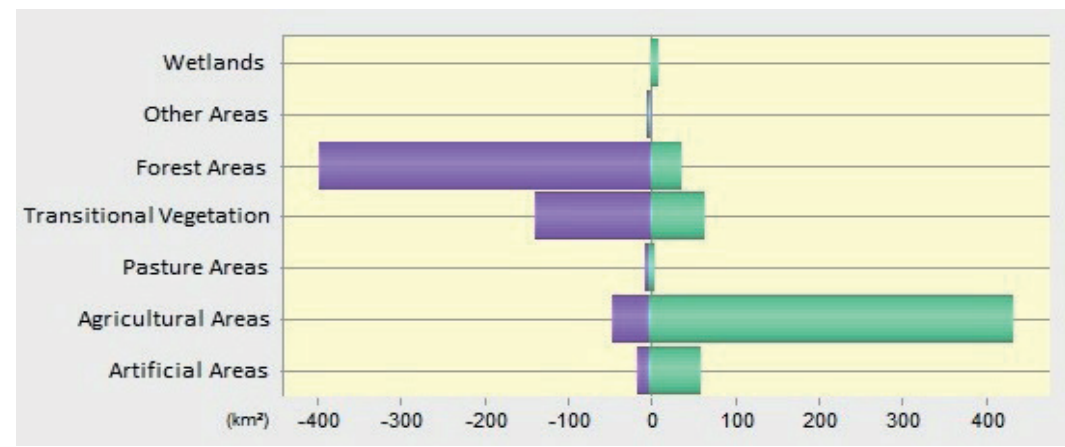

Figure 11: Gains and losses in Düzce province land use/land cover (1990-2018).

Table 11: The transformation of land use/land cover in Düzce province between 1990-2018 (km²).

\begin{tabular}{|c|c|c|c|c|c|c|c|}
\hline LU/LC* & Artificial Areas & Agricultural Areas & Agricultural Areas & Pasture Areas & Transitional Vegetation & Wetlands & Other Areas \\
\hline Artificial Areas & - & 49.4 & 4.1 & 2.8 & 5.5 & - & 2.1 \\
\hline Agricultural Areas & 11.1 & - & 272.2 & 1.3 & 158.2 & 0.1 & 1.2 \\
\hline Forest Areas & 0.3 & 4.7 & - & 0.1 & 30.5 & - & - \\
\hline Pasture Areas & - & 2.9 & 1.1 & - & 2.1 & - & - \\
\hline Transitional Vegetation & - & 1.5 & 60.4 & 1.3 & - & - & 0.4 \\
\hline Wetlands & - & 1.7 & - & 2 & 1.8 & - & 2 \\
\hline Other Areas & - & - & - & - & 1 & - & - \\
\hline
\end{tabular}

* Values in rows represent area gained from plots in column section. $\left(\mathrm{km}^{2}\right)$

2018). However, it is understood that the studies conducted are not sufficient to protect the forests.

$\mathrm{LU} / \mathrm{LC}$, which is the second largest area after forest cover, belongs to agricultural areas. In the period from 1990 to 2018, agricultural lands expanded by $383 \mathrm{~km}^{2}$ approximately. During this period, $267 \mathrm{~km}^{2}$ of the agricultural lands were obtained from the forest, $157 \mathrm{~km}^{2}$ from transitional vegetation, $11 \mathrm{~km}^{2}$ from artificial areas. However, approximately $50 \mathrm{~km}^{2}$ of the agricultural lands have turned into artificial areas (Table 11). The need for agricultural land has increased to meet the needs of the increasing population. For this reason, the LU/LC that expands the most area in the study area are agricultural areas. LU/LC, which is spread over another large area in Düzce province, belongs to transitional vegetation.

Between 1990 and 2018, there was a loss of $135 \mathrm{~km}^{2}$ in transitional vegetation areas. This situation emerged by turning $157 \mathrm{~km}^{2}$ into agriculture areas, $6 \mathrm{~km}^{2}$ into artificial areas and 2 $\mathrm{km}^{2}$ into wetlands. The transitional vegetation areas gained from approximately $30 \mathrm{~km}^{2}$ of forest cover. Areas belonging to transitional vegetation cover were between agricultural and forest areas. It is understood that a significant part of these areas has turned into agricultural areas over time.
The fourth wide-spread class in Düzce province belongs to artificial areas. During the 28 years, artificial areas have expanded by approximately $52 \mathrm{~km}^{2}$. This LU/LC class has expanded its surface with $38 \mathrm{~km}^{2}$ of agriculture, $5 \mathrm{~km}^{2}$ of transitional vegetation, $4 \mathrm{~km}^{2}$ of forest, $3 \mathrm{~km}^{2}$ of pasture, and 2 $\mathrm{km}^{2}$ of land gained from other areas (Figure 12). It is observed that residential areas, which constitute a significant part of artificial areas, have been transformed from agricultural lands. An important part of this expansion took place in Düzce plain and its immediate surroundings. In this respect, it is understood that artificial areas, especially settlements, occupy arable lands. With the increase in urbanization, the higher income in the agricultural lands around the urban area compared to the agricultural income caused these areas to rapidly turn into residential areas (Bayar and Karabacak, 2017).

While there was no significant change in the lands belonging to the pasture cover, one of the LU/LC areas in the study area, the area covered by wetlands, has increased by $5 \mathrm{~km}^{2}$ approximately and almost doubled. As mentioned before, the conservation studies carried out in 1992 and 2014 for Efteni Lake by the Ministry of Forestry and Water Affairs were effective in this situation. $2 \mathrm{~km}^{2}$ of land belonging to other areas in the LU/ LC classes were lost. It is understood that the anthropogenic effect is more limited in LU/LC classes belonging to pasture and other areas than in others. 


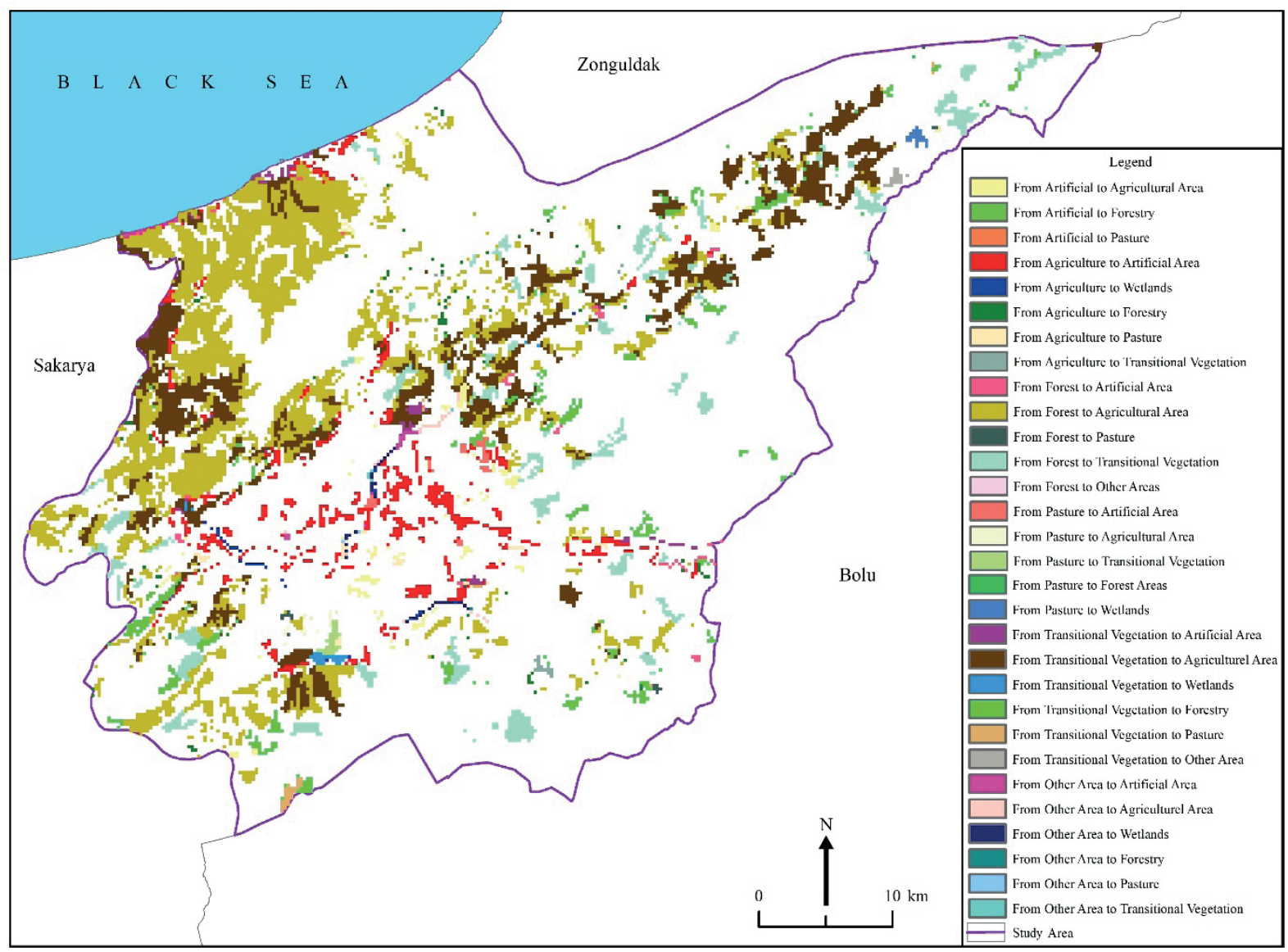

Figure 12: Transitions between land use/land cover categories in the Düzce province between 1990 and 2018.

\section{CONCLUSION}

In this study, the land use and land cover changes in Düzce province in 1990, 2000 and 2018 were examined using the CORINE database. While there was no significant change in LU/ LC between 1990 and 2000, significant changes occurred between 2000 and 2018. The land cover characteristics covering the largest area in Düzce province are forests. It is followed by agricultural land. Additionally, there is a relationship between forest areas and agricultural lands. At the same time, there was a contraction in agricultural areas during the period between 1990 and 2000, even if to a small extent forest areas tended to expand. This situation was realized with the land registry cadastre works carried out between 1990 and 2000 and the forest land occupied by the agricultural lands was converted back into the forest. However, while the forest areas contracted, the agricultural areas have expanded after 2000. Whereas the ratio of forest areas in the total LU/LC was approximately $62 \%$ in 2000 , this rate decreased to $48 \%$ in 2018 . While the agricultural land rate was $27 \%$ in 2000 , it increased to $43 \%$ in 2018 . The forest areas in the west and east of Düzce plain and the forest area in the south of
Akçakoca have turned into agricultural areas. have turned into agricultural areas. While the annual decrease rate of forest areas is $1.2 \%$, the annual increase rate of agricultural areas is $3.1 \%$. In this respect, although various public institutions have carried out some studies to protect forest areas, it is understood that these implementations are not sufficient. The relevant public institutions should protect the forest areas; implementations for afforestation and rehabilitation must be actualized.

There has been a significant decrease in transitional vegetation areas in the study area between 1990 and 2018. The areas belonging to transitional vegetation cover approximately $10 \%$ of Düzce Province's area in 1990 and constitute $4 \%$ in 2018. It is seen that the areas belonging to the aforementioned land cover have decreased by $60 \%$ approximately in the last 28 years. Areas belonging to transitional vegetation, generally located between forest and agricultural land, are mostly occupied by agricultural lands.

The artificial areas in the study area have been in continuous expansion since 1990. The need for socioeconomic areas, 
especially with the increase in population, affected this situation. Besides, after Düzce became a province in 1999, some factors; the opening of new zoning areas, the increase in the number of buildings, the opening of the OIZ, the passing of the İstanbulAnkara Highway through the provincial borders, and the foundation of Düzce University has caused an increase in artificial areas throughout the province. In this regard, artificial areas, which covered $1.6 \%$ of Düzce province in 1990, became $3.7 \%$ in 2018. The development of residential areas, which constitutes a significant part of the artificial areas, took place along the Düzce plain and its immediate surroundings and the coastal area in Akçakoca. Most of the artificial areas in Düzce province have expanded over agricultural areas. The urban of Düzce, which constitutes the largest settlement in the study area, expanded over time and united with the residential areas. The annual growth rate of artificial areas is $7.5 \%$. In this regard, it is predicted that settlements around the city will also be included in the city over time. As a result of this expansion, other natural elements, especially agricultural areas, will be damaged. There has been an increase of $80 \%$ in the wetlands in the study area compared to 1990. The protection of Lake Efteni and its immediate surroundings by the Ministry of Forestry and Water Affairs in 1992 was effective on this increase. Besides, with the decision taken by the National Wetland Commission in 2014, the lake surface expansion works within the scope of the "Efteni Lake Wetland Management Plan" were also effective. Apart from these, there has not been a significant change in LU/LC of pastures and other areas whose area is more limited in Düzce province.

The artificial areas in the study area have seen continuous expansion since 1990. The need for socioeconomic areas, especially with the increase in population, affected this situation. Besides, after Düzce became a province in 1999, some factors; the opening of new zoning areas, the increase in the number of buildings, the opening of the OIZ, the passing of the İstanbulAnkara Highway through the provincial borders, the establishment of Düzce University have caused an increase in artificial areas throughout the province. In this regard, artificial areas, which covered 1.6\% of Düzce province in 1990, became $3.7 \%$ in 2018. The development of residential areas, which constitute a significant part of the artificial areas, took place along the Düzce plain, its immediate surroundings and the coastal area in Akçakoca. Most of the artificial areas in Düzce province have expanded over agricultural areas. The urban of Düzce, which constitutes the largest settlement in the study area, expanded over time and united with the residential areas. The annual growth rate of artificial areas is $7.5 \%$. In this regard, it is predicted that it will also include around the urban over time. As a result of this expansion, other natural elements, especially agricultural areas, will be damaged. There was an increase of $80 \%$ in wetlands in the study area from 1990 to 2018. The protection of Lake Efteni and its immediate surroundings by the Ministry of Forestry and Water Affairs in 1992 had an impact on this increase. Besides, with the National Wetland Commission's decision in 2014, the lake surface expansion works within the scope of "Efteni Lake Wetland Management Plan" had also had an effect on increase. Apart from these, there has not been a significant change in LU/LC of pastures and other areas whose area is more limited in Düzce province.

\section{Recommendations}

Human activities have played the most active role in LU/LC in Düzce province. Especially the earthquake which occurred in 1999 and then Düzce becoming province has reasoned the land use pattern changings. Besides the government's support for development, new areas that opened to construction have caused the expansion of artificial lands. After the earthquake, Bahçeşehir district (Kalıc1 Konutlar) has built on sloping land on the northeast of the city and covers approximately $6 \mathrm{~km}^{2}$ area. However, it is more reasonable to use these lands as a residential area compared to Düzce plain in terms of both preventing damages from any possible earthquake and preventing the occupation of fertile agricultural areas. This district has become almost the edge city with a population of 25 thousand. The distance between the Bahçeşehir district and the downtown is 3 $\mathrm{km}$ and completely first class agricultural land. This area in between may be under the risk of occupation by the settlements over time. TOKI's that were built in the northeast of the city is an indication of this. However, the development should occur towards the north and east sloping lands of Bahçeşehir's vicinity. This situation is highly crucial for protecting these agricultural lands and preventing getting damaged by any possible earthquake. The establishment of Düzce University in the north of the city in 2006 and the construction activities related to this have spread on approximately $1.8 \mathrm{~km}^{2}$ area. This choice is convenient because this area is on sloping land and sixth, seventh-class lands. The university campus must develop in this area without spreading to any different points.

Industrial establishments form a part of the artificial areas at various points on the Düzce plain, almost all of which comprise first class land. A significant part of these have been active in the 2000s and expanded its area. One of them is a small industrial zone $\left(0.7 \mathrm{~km}^{2}\right)$ located west of the city and north of the D-100 
(Adapazarı road). Also, along with the D-100, there are various industrial establishments. Such as textile, pipe, and automotive along the Bolu road. Besides, the OIZ $\left(1.5 \mathrm{~km}^{2}\right)$ located approximately $5 \mathrm{~km}$ south of the city and another $\operatorname{OIZ}\left(1.2 \mathrm{~km}^{2}\right)$ located to the east are important employment investments. However, these industrial establishments are located on agricultural lands. This means that the land in Düzce province is not under appropriate usage for its purpose. Also, the mountains around the Düzce plain affect the accumulation of polluted air and adversely affect the city's ventilation. In this regard, direct industrial activities towards the sloping lands located on the edge of the plain and the wind direction should be considered while constructing. Besides, if the industrial establishments located at various points of the Düzce plain are agglomerated, geographical concentration and agricultural land will be less occupied.

Generally, there are forests and transitional vegetation on sixth and seventh-class lands in Düzce province. These areas, which need to be protected as forests, have been turned into agricultural areas and land degradation has occurred. These lands need to be rehabilitated and protected as forest and transitional vegetation areas. In addition, organizations can be made for tourism in these lands without damaging nature and forests. Located within the borders of the province; Güzeldere Waterfall $(650 \mathrm{~m})$, Aydınpınar Waterfall $(330 \mathrm{~m})$, Odayeri Plateau (1,200 m), Kardüz Plateau (1,830 m), Kızık Plateau (1,600 m), Derebalık Plateau (1,400 m), Pürenli Plateau (1,400 $\mathrm{m})$, located within the borders of the province. Güzeldere Waterfall $(650 \mathrm{~m})$, Aydınpınar Waterfall $(330 \mathrm{~m})$, Odayeri Plateau (1,200 m), Kardüz Plateau (1,830 m), Kızık Plateau (1,600 m), Derebalık Plateau (1,400 m), Pürenli Plateau (1,400 m), Hera Plateau (1.500 m), Balıklı Plateau (1,400), Sinekli Plateau $(1450 \mathrm{~m})$, Topuk Plateau and Pond (1.280) can be organization areas for tent camps, trekking, photo-safari, offroad and for various festivals. In addition to these, should increase pasture improvement practices to improve rangeland livestock. For this, pasture areas should be fertilized to increase grass production and the nutritional value of grass.

In sum, the human factor is the main reason for the change in land cover in Düzce province. The transformation of land belonging to the forest and transitional vegetation into agricultural land confirms this. Also, the transformation of agricultural lands into artificial areas indicates improper land use. As a matter of fact, while $14.4 \%$ of the lands suitable for cultivated agriculture in the first and fourth classes are allocated to artificial areas, $34 \%$ of the lands in the last four classes that are not suitable for agriculture are used as agricultural land. First, forest areas need to be rehabilitated for proper use, such as it was done between 1990-2000. After that, should develop artificial areas on the sloping lands around the Düzce plain or the plain's edges. Considering that Düzce is located in the first degree seismic zone, it should avoid construction on the poor and alluvial ground. In this respect, plans should be made by the area's natural environment characteristics by including shareholders such as public institutions, universities, nongovernmental organizations, and local people.

Peer-review: Externally peer-reviewed.

Conflict of Interest: The authors have no conflict of interest to declare.

Grant Support: The authors declared that this study has received no financial support.

Hakem Değerlendirmesi: Dıș bağımsız.

Çıkar Çatışması: Yazarlar çıkar çatışması bildirmemiştir.

Finansal Destek: Yazarlar bu çalışma için finansal destek almadığını beyan etmiştir

\section{REFERENCES/KAYNAKÇA}

Altürk, B. (2017). Arazi kullanım/arazi örtüsü değişikliğinin ve su kaynaklarına etkisinin belirlenmesi: Ergene Havzası örneği. (Doktora Tezi). Namık Kemal Üniversitesi, Fen Bilimleri Enstitüsü, Tekirdağ.

Anderson, J. R., Hardy, E. E., Roach, J. T. \& Witmer, R. E. (1976). A land use and land cover classification system for use with remote sensor data. U.S. Geological Survey, Virginia: Professional Paper 964.

Balzter, H., Cole, B., Thiel, C. \& Schmullius, C. (2015). Mapping CORINE Land Cover from Sentinel-1A SAR and SRTM Digital Elevation Model Data using Random Forests. Remote Sensing, 7, 14876 14898.

Başyiğit, L. (2004). CORINE Arazi Kullanımı Sınıflandırma Sistemine Göre Arazi Kullanım Haritasının Hazırlanması: Isparta Örneği. Tarlm Bilimleri Dergisi, 10(4), 366-374.

Bayar, R. (Tarihsiz). Arazi kullanımı (land use) ders notları. Ankara: Ankara Üniversitesi, DTCF Coğrafya Bölümü.

Bayar, R. ve Karabacak, K. (2017). Ankara ili arazi örtüsü değişimi (2000-2012). Coğrafi Bilimler Dergisi, 15(1), 59-76.

Bossard, M., Feranec, J. \& Otahel, J., (2000). CORINE Land Cover Technical Guide - Addendum 2000. Copenhagen: European Environment Agency, Vol. 40. Technical Report.

Brewington, L. (2020). Transitions and drivers of land use/land cover change in Hawaii: A case study of Maui, In Editors: Walsh, S.J., Riveros-Iregui, D., Acre-Nazario, J. \& Page, P.H (Eds), Land cover and land use change on Islands, (pp. 89-117).

Campbell J. B., (1981). Spatial correlation effects upon accuracy of supervised classification of land cover. Photogrammetric Engineering And Remote Sensing, 47(3), 355-363.

Di Gregorio, A. \& L. J. M. Jansen, (2000). Land cover Classification System (LCCS): Classification Concepts and User Manual. Rome: Environment and Natural Resources Service (SDRN), FAO. 
Feranec, J., Jaffrain, G., Soukup, T. \& Hazeu, G. (2010). Determining changes and flows in European landscapes 1990-2000 using CORINE land cover data. Applied Geography, 30, 19-35.

Fisher, P., Comber, A. \& Wadsworth, R., (2005). Land use and land cover: Contradiction or Complement. Peter Fisher \& David J. Unwin (Eds), Re-Presenting GIS, Leicester: John Wiley and Sons Ltd.

Garipağaoğlu, N. ve Duman, E., (2018). Çatalca ilçesinin arazi kullanımında meydana gelen değişimler (1987-2016). Marmara Coğrafya Dergisi, 37, 219-232.

Gözenç, S. (1978). Küçük Menderes Havzasında arazinin kullanılıș ve sinıflandırllmast. İstanbul: İstanbul Üniversitesi Yayınları No. 2396, Edebiyat Fakültesi Basımevi.

Gözenç, S. (1980). Arazi kullanma 'Land Use' haritalarında standardizasyon ve Türkiye için bir öneri. İstanbul Üniversitesi Coğrafya Enstitüsü Dergisi, 23, 37-46.

Gözenç, S. (1977). Arazinin kullanılması ve değerlendirilmesinin coğrafi yönden tetkiki. İstanbul Üniversitesi Coğrafya Enstitüsü Dergisi, 20-21, 169-179.

Grigorescu, I., Kucsicsa, G., Popovici, E., Mitrică, B., Dumitras, cu, M. \& Mocanu, I., (2018). Regional disparities in the urban sprawl phenomenon in Romania using CORINE land cover database. Romanian Journal of Geography, 62, 169-184.

Gülersoy, A. E. (2013). Çorum Merkez İlçede Arazi Kullanımının Zamansal Değişimi (1987-2011) ve Çevresel Etkileri. Coğrafi Bilimler Dergisi, CBD 11(2), 169-194.

Gülersoy, A. E. (2013). Farklı Uzaktan Algılama Teknikleri Kullanılarak Arazi Örtüsü/Kullanımında Meydana Gelen Değişimlerin İncelenmesi: Manisa Merkez İlçesi Örneği (1986-2010). Turkish Studies International Periodical For The Languages, Literature and History of Turkish or Turkic Volume 8/8 Summer, 1915-1934.

Gülersoy, A. E. (2014). Seferihisar'da Arazi Kullanımının Zamansal Değişimi (1984-2010) ve İdeal Arazi Kullanımı İçin Öneriler. SDÜ Fen Edebiyat Fakültesi Sosyal Bilimler Dergisi, 31, 155-180.

Gülersoy, A. E. (2014). Küçük Menderes Havzası'nda Mekânsal Potansiyel ile Arazi Kullanımı Arasındaki İlişkiler. ISBN: 978-60585185-0-6. Bassaray Matbaas1, İzmir.

Hua, W., Chen, H. \& Sun, S. (2015). Assessing climatic impacts of future land use and land cover change projected with the CanESM2 Model [J]. International Journal of Climatology, 35(12), 3661-3675.

Janssen, S., Dumont, G., Fierens, F. \& Mensink, C. (2008). Spatial interpolation of air pollution measurements using CORINE Land Cover Data. Atmospheric Environment, 42, 4884-4903.

Karademir, D. ve Doğan, M. (2019). Kilis ilinde arazi kullanımında meydana gelen değişimler. Journal of Awareness, 4(3), 329-342.

Karakaş Özür, N. ve Ataol, M. (2018), Coğrafya araştırmalarında CORINE verilerinin kullanılması. Türkoğlu, N., Bayar, R., Karabacak, K., Kurtar Anlı, C., Kılar, H. ve Gökkaya, E. (Ed)., Ankara: TÜCAUM 30. Yıl Uluslararası Coğrafya Sempozyumu International Geography Symposium on the 30th Anniversary of TUCAUM 3-6 Ekim 2018 /3-6 October 2018.

Karakaş Özür, N. ve Ataol, M., (2018), Türkiye'de CORINE verilerinin kullanılmasına dair değerlendirme. ÇKÜ Sosyal Bilimler Enstitüsü Dergisi, 9(2), 110-130.
Karakuş, C. B., Cerit, O. ve Kavak, K. S. (2015). The Impact of Land Use/Land Cover (LU/LC) changes on land surface temperature in Sivas city center and its surroundings and assessment of urban heat island. Procedia Earth and Planetary Science, 15, 454-461.

Kupkova, L., Bičík, I. \& Zdeněk B. (2019). Long-term land use/land cover changes in Czech border regions. Acta Geographica Slovenica, 59(2), 107-117.

Mark, M. \& Kudakwashe, M. (2010). Rate of Land Use/Land Cover changes in Shurugwi district, Zimbabwe: Drivers for change. Journal of Sustainable Development in Africa, 12(3), 107-121.

Özçağlar, A. (1995). Çarşamba Ovası ve yakın çevresinde araziden faydalanma. Türkiye Coğrafyası Araştırma ve Uygulama Merkezi Dergisi, 3, 93-128.

Özçağlar, A. (Tarihsiz), Arazi kullanımı (land use) ders notları. Ankara: Ankara Üniversitesi, DTCF Coğrafya Bölümü.

Özdeş, M., Özşahin, E. ve Eroğlu, E. (2019). Corine arazi sınıflandırmasına göre Trakya Yarımadası arazi örtüsü/kullanımı özelliklerinin yeniden değerlendirilmesi. Gönençgil, B., Ertek, A., Akova, İ. ve Elbaşı, E. (Ed.), İstanbul: İstanbul Uluslararası Coğrafya Sempozyumu Bildiriler Kitabı, 679-686.

Pérez-Hoyos, A., García-Haro, F. J. \& San-Miguel-Ayanz, J. (2012). Conventional and fuzzy comparisons of large scale land cover products: Application to CORINE, GLC2000, MODIS and GlobCover in Europe. ISPRS Journal of Photogrammetry and Remote Sensing, 74, 185-201.

Sandal, E., Adıgüzel, F., Karademir, N. (2020). Changes in land use between the years of 1990-2018 in Mersin province based on CORINE (Coordination of Information on The Environment) System. Kastamonu Üniversitesi Mühendislik ve Fen Bilimleri Dergisi (KUJES), 6(1), 8-18.

Sarı, E. ve Özşahin, E., (2016). CORINE sistemine göre Tekirdağ ilinin LU/LC (Arazi Kullanımı/Arazi Örtüsü) özelliklerinin analizi. Alınteri Dergisi, 30(B), 13-26.

Republic of Turkey Ministry of Agriculture and Forestry. (2019). Su Yönetimi Genel Müdürlüğü, 03-05 Nisan 2019 Su Kalitesi Yönetimi Hizmet İçi Eğitimi’nde sunulmuştur. Antalya, Türkiye.

Republic of Turkey Ministry of Agriculture and Forestry Düzce Directorate of Provincial Agriculture and Forestry. (2013). Düzce Tarımsal Kuraklık Eylem Planı (2013-2017), Düzce.

Tunçdilek, N. (1985). Türkiye'de relief şekilleri ve arazi kullanımı. İstanbul: İstanbul Üniversitesi Deniz Bilimleri ve Coğrafya Enstitüsü Yayınları No: 3, İÜ Yay. No: 3279.

Turkish State Meteorological Service. Düzce İstasyonu Uzun Yıllar Ortalama İklim Verileri (1959-2019). TÜMAS. Ankara.

Verburg, P. H., Kok, K., Pontius, R. G., \& Veldkamp, A. (2004). Modeling land use and land cover change. Global Change - The IGBP Series, 117-135.

William B. Meyer \& B L Turner II, (1996). Land-use/land-cover change: Challenges for geographers, GeoJournal, 39(3), 237-240. 


\section{Internet Sources}

Republic of Turkey Ministry of Agriculture and Forestry. (2020, August 29). https://corine.tarimorman.gov.tr/corineportal/amac.html

Ministry of Forestry and Water Affairs, Düzce Development Plan (2014-2018), (2020, September 10). https://docplayerbiz. tr/16317045-Orman-ve-su-isleri-bakanligi-duzce-gelisim-plani. html.
Toprak Koruma ve Arazi Kullanımı Kanunu (2020, September 12). https://www.resmigazete.gov.tr/eskiler/2005/07/20050719-2.ht$m \#: \sim:$ ext $=$ MADDE\%201.\%20\%E2\%80\%94\%20Bu\%20Kanunun $\% 20$ amac\% $\% 4 \% 1$, sa\% C4\%9Flayacak\%20us\%C3\%BBl\%20ve\%20esaslar $\% C 4 \% B 1 \% 20$.

Coffey, R. (2020, August 1). Michigan State University Extension, The difference between "land use" and "land cover", Retrieved August 1, 2020 from https://www.canr.msu.edu/news/the_difference_between_land_use_and_land_cover. 